\title{
Ultrastructural description of Ceratomyxa microlepis sp. nov. (Phylum Myxozoa): a parasite infecting the gall bladder of Hemiodus microlepis, a freshwater teleost from the Amazon River
}

\author{
Carlos Azevedo ${ }^{1,2} /^{+}$, Sónia Rocha ${ }^{2}$, Graça Casal ${ }^{2,3}$, Sérgio Carmona São Clemente ${ }^{4}$, \\ Patrícia Matos ${ }^{5}$, Saleh Al-Quraishy ${ }^{6}$, Edilson Matos ${ }^{7}$ \\ 1'Departmento de Biologia Celular, Instituto de Ciências Biomédicas, Universidade do Porto, Porto, Portugal ²Laboratório de Patologia, \\ Centro Interdisciplinar de Investigação Marinha e Ambiental, Porto, Portugal ${ }^{3}$ Departamento de Ciências, Instituto Superior de \\ Ciências da Saúde-Norte, Gandra, Portugal ${ }^{4}$ Laboratório de Inspeção e Tecnologia de Alimentos, Faculdade de Veterinária, \\ Universidade Federal Fluminense,Niterói, RJ, Brasil ${ }^{5}$ Laboratório de Pesquisa Edilson Matos, Instituto de Ciências Biológicas, \\ Universidade Federal do Pará, Belém, PA, Brasil ${ }^{~}$ Zoology Department, College of Science, King Saud University, Riyadh, \\ Saudi Arabia ${ }^{7}$ Laboratório de Pesquisa Carlos Azevedo, Universidade Federal Rural da Amazônia, Belém, AM, Brasil
}

A new ceratomyxid parasite was examined for taxonomic identification, upon being found infecting the gall bladder of Hemiodus microlepis (Teleostei: Hemiodontidae), a freshwater teleost collected from the Amazon River, Brazil. Light and transmission electron microscopy revealed elongated crescent-shaped spores constituted by two asymmetrical shell valves united along a straight sutural line, each possessing a lateral projection. The spores body measured $5.2 \pm 0.4 \mu \mathrm{m}(n=25)$ in length and $35.5 \pm 0.9 \mu \mathrm{m}(n=25)$ in total thickness. The lateral projections were asymmetric, one measuring $18.1 \pm 0.5 \mu \mathrm{m}(n=25)$ in thickness and the other measuring $17.5 \pm 0.5 \mu \mathrm{m}(n=25)$ in thickness. Two equal-sized subspherical polar capsules measuring $2.2 \pm 0.3 \mu \mathrm{m}$ in diameter were located at the same level, each possessing a polar filament with 5-6 coils. The sporoplasm was binucleate. Considering the morphometric data analyzed from the microscopic observations, as well as the host species and its geographical location, this paper describes a new myxosporean species, herein named Ceratomyxa microlepis $s p$. nov.; therefore representing the first description of a freshwater ceratomyxid from the South American region.

Key words: Ceratomyxa microlepis sp. nov. - gall bladder - Hemiodus microlepis freshwater teleost - Amazon River - ultrastructure

The genus Ceratomyxa Thélohan, 1892, constitutes one of the largest genera within the class Myxosporea of the phylum Myxozoa, comprising about 190 species, the great majority of which are coelozoic parasites infecting the gall bladder of marine teleosts (Eiras 2006, Lom \& Dyková 2006). Ceratomyxa spp have elongated, crescent-shaped or arcuate spores with shell valves that are frequently conical, exceeding in length the axial diameter of the spore. Spores contain two subspherical capsules and a binucleate sporoplasm or, more rarely, two uninucleate sporoplasms (Lom \& Dyková 1992).

Despite having a worldwide distribution, only three species of Ceratomyxa have been described from South American fish hosts: Ceratomyxa dissostichi from Dissostichus eleginoides from the Falklands islands, $\mathrm{Ce}$ ratomyxa curvata from Odontaspis americanus and $\mathrm{Ce}$ ratomyxa hippocampi from Hippocampus punctulatus,

Financial support: Eng A Almeida Foundation (Portugal), CNPq, CAPES, Visiting Professor Program of College of

Science, King Saud University, Riyadh (Saudi Arabia)

+ Corresponding author: azevedoc@icbas.up.pt

Received 3 May 2012

Accepted 28 May 2012 both from the Brazilian Atlantic coast (Cunha \& Fonseca 1918, Brickle et al. 2001). These are all species infecting the gall bladder of marine fish hosts. In fact, only five species have been reported from freshwater teleosts worldwide: Ceratomyxa anguillae from the gall bladder of Anguilla anguilla from France, Ceratomyxa hilsae from the gall bladder of Hilsa ilisha from India, Ceratomyxa hongtzensis from the gall bladder of Pelteobagrus eupogon from China, Ceratomyxa hungarica from the gall bladder of Proterorhinus marmoratus from Hungary and Ceratomyxa shasta from the digestive tract of Oncorhynchus mykiss from the United States of America (Chakravarty 1939, Noble 1950, Tuzet \& Ormières 1957, Hsieh \& Chen 1984, Molnár 1992). Of the five mentioned freshwater species, only C. shasta is histozoic (Noble 1950).

The present paper uses light microscopy and transmission electronic microscopy to describe a new myxosporean species of the genus Ceratomyxa found infecting the gall bladder of Hemiodus microlepis. The host species is a teleost that inhabits the Amazon River, making this the first description of a freshwater ceratomyxid species from the South American region.

\section{MATERIALS AND METHODS}

Twenty five specimens (15 females and 10 males) of H. microlepis Kner, 1858 (Teleostei: Hemiodontidae), known by the Brazilian common name Orana 
and displaying an average body length of 14-22 cm, were collected from the Trombetas River, an affluent located at about $770 \mathrm{~km}$ from the mouth of the Amazon River $\left(01^{\circ} 45^{\prime} \mathrm{S} 55^{\circ} 51^{\prime} \mathrm{W}\right)$, near the city of Oriximiná in the state of Pará (PA), Brazil. Upon necropsy, the gall bladder of each specimen was examined for parasitic infection. Small fragments of infected gall bladder tissue and bile were examined using Nomarski differential interference contrast microscopy, equipped with a micrometric ocular lens and image software. Fresh spore measurements were taken.

For transmission electron microscopy (TEM), the bile of the infected gall bladders was fixed in 5\% glutaraldehyde in $0.2 \mathrm{M}$ sodium cacodylate buffer ( $\mathrm{pH} 7.4)$ for $24 \mathrm{~h}$ at $4^{\circ} \mathrm{C}$. The solution was then washed overnight in the same buffer at $4^{\circ} \mathrm{C}$ and postfixed in $2 \% \mathrm{OsO}_{4}$, buffered with the same solution for $4 \mathrm{~h}$ at the same temperature. After dehydration in a graded ethanolseries followed by propylene oxide, samples were embedded in Epon. Semi-thin sections were stained with methylene blue-Azur II. Ultrathin sections were cut with a diamond knife, double-stained with uranyl acetate and lead citrate and observed in a JEOL 100CXII TEM operated at $60 \mathrm{kV}$.

\section{RESULTS}

Light microscopy revealed mature spores of an undescribed Ceratomyxa species floating free in the bile (Figs 1-3), but no other sporogenic developmental stages were observed. The infection was detected in the gall bladder of $36 \%$ of the H. microlepis examined, but no obvious morphological and behavioural symptoms of infection were observed.

\section{Ceratomyxa microlepis sp. nov.} (Figs 1-9)

Description - The spores displayed crescent-shape with a convex anterior pole and a slightly concave posterior pole (Figs 1-3), measuring $5.2 \pm 0.4 \mu \mathrm{m}(\mathrm{n}=25)$ in length and $35.5 \pm 0.9 \mu \mathrm{m}(\mathrm{n}=25)$ in total thickness (Figs 1,3). Two asymmetric conical shell valves united along a straight sutural line (Figs 4, 7), each possessing an elongated lateral projection with slightly different thickness and shape (Figs 1, 3). In one shell valve, the lateral projection was $18.1 \pm 0.5 \mu \mathrm{m}(\mathrm{n}=25)$ thick and tapered into a blunt end, while in the other shell valve, the lateral projection was $17.5 \pm 0.5 \mu \mathrm{m}(\mathrm{n}=25)$ thick and displayed a rounded end (Figs 1,3). The lateral projections were a continuation of the cytoplasmic material of the spore, as well as of the wall of the shell valves, which was comprised of a continuous external layer of dense material and a continuous internal layer of lighter material (Figs 4, 5, 6, 8). Two equal-sized subspherical polar capsules were located side by side and measured $2.2 \pm 0.3 \mu \mathrm{m}$ in diameter $(\mathrm{n}=30)$ (Figs 3,4 , 6 ). The wall of these polar capsules was comprised of a continuous external dense layer and an internal hyaline layer (Fig. 5), which displayed extrusion pores located near the sutural line at the anterior pole of the spore. An electron dense stopper closed each extrusion pore, pre- venting extrusion of the polar filament (Fig. 4). Inside the polar capsules the isofilar polar filament coiled in five-six turns and appeared obliquely arranged, forming an angle of about $58^{\circ}-60^{\circ}$ to the longitudinal axis of these structures (Figs 4, 5). The sporoplasm was irregular in shape and displayed two nuclei randomly positioned in its matrix (Figs 4, 6). The cytoplasm of the shell valves contained several dense reserve bodies and vesicles (Fig. 8). A schematic drawing of a spore is shown in Fig. 9, allowing recognition of its overall ultrastructural aspects.

Type host - H. microlepis Kner, 1858 (Teleostei: Hemiodontidae).

Site of infection - Mature spores were found floating free in the bile. Spores were not observed attached to the epithelial tissue of the gall bladder.

Type locality - Trombetas River (01ํㄱ' $\left.55^{\circ} 51^{\prime} \mathrm{W}\right)$, an affluent of the Amazon River located $770 \mathrm{~km}$ upstream from its mouth, near the city of Oriximiná, PA.

Type data and depository (upon acceptance) - A glass slide containing a semi-thin section of mature spores of the hapantotype was deposited in the International Myxozoan Type Slide Collection at the National Institute of Amazonian Research, Manaus, state of Amazonas, Brazil, under acquisition (012/12).

Prevalence of infection - Nine out of 25 (36\%) specimens were infected [5/15 (33.3\%) for females and 4/10 $(40 \%)$ for males].

Etymology - The specific epithet of this parasite derives from the specific epithet of the host species.

\section{DISCUSSION}

Despite the numerous descriptions relating to the genus Ceratomyxa, only $C$. anguillae, $C$. hilsae, $C$. hongtzensis, $C$. hungarica and $C$. shasta are known to infect freshwater teleosts, none of which are from the South American region (Eiras 2006, Lom \& Dyková 2006). With the exception of C. shasta, which is histozoic (Noble 1950), all the other freshwater species of the genus Ceratomyxa are coelozoic (Chakravarty 1939, Tuzet \& Ormières 1957, Hsieh \& Chen 1984, Molnár 1992). The parasite here described was also coelozoic in the gall bladder of $H$. microlepis, but displayed ultrastructural characteristics very distinct from those reported for the other freshwater species within the genus, as shown in Table. The most prominent of which was the presence of two elongated lateral projections, which are missing in the remaining freshwater species of the genus.

Although all other currently known species of $\mathrm{Ce}$ ratomyxa infecting freshwater fish lack elongated lateral projections, there are about 70 marine species of $\mathrm{Ce}$ ratomyxa in which such projections have been described (Ali et al. 2006, Eiras 2006, Abdel-Ghaffar et al. 2008, Gunter \& Adlard 2008, 2009, Gunter et al. 2010). Morphological comparison to these marine species suggested that $C$. microlepis sp. nov. shared some superficial similarity with Ceratomyxa aglomerata from the 


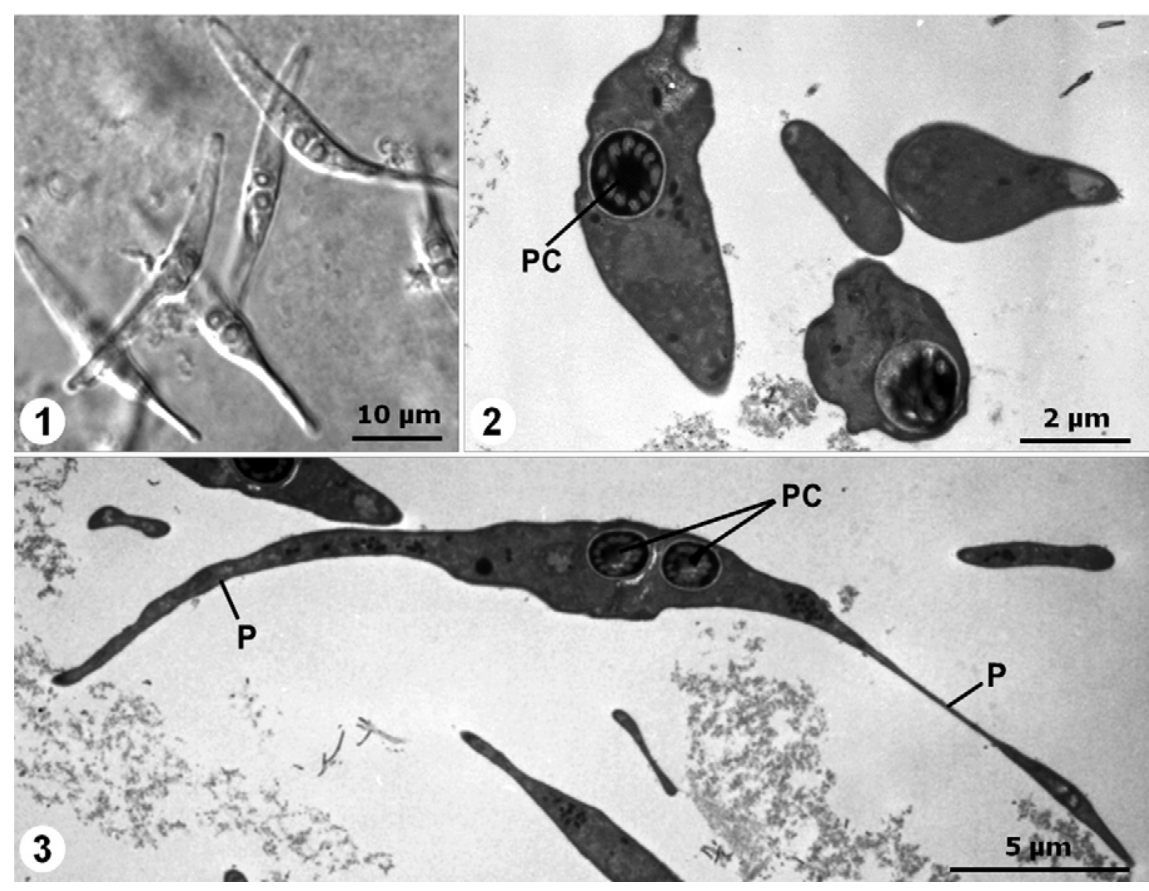

Figs 1-3: light and transmission electron micrographs of Ceratomyxa microlepis sp. nov. infecting the gall bladder of Hemiodus microlepis collected from the Amazon River. 1: several free unfixed spores observed by differential interference contrast microscopy; 2: spores sectioned at different levels and displaying different ultrastructural aspects, including the polar capsules (PC); 3: longitudinal section of a spore revealing its general organization, namely the two lateral projections (P) and the two PCs.
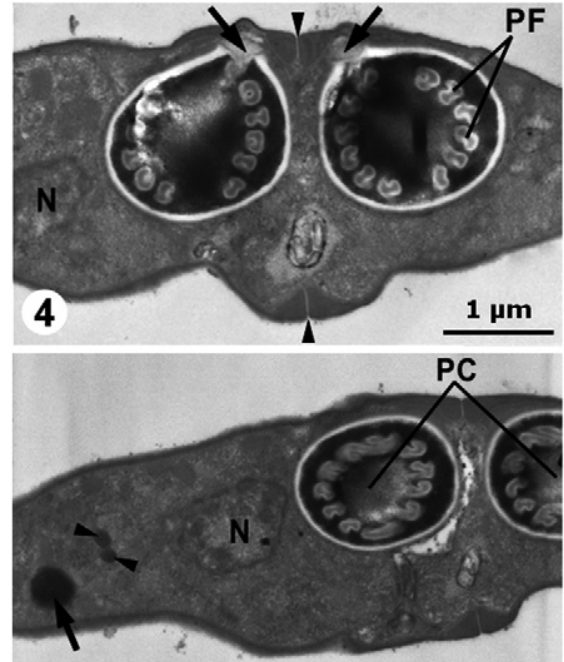

6
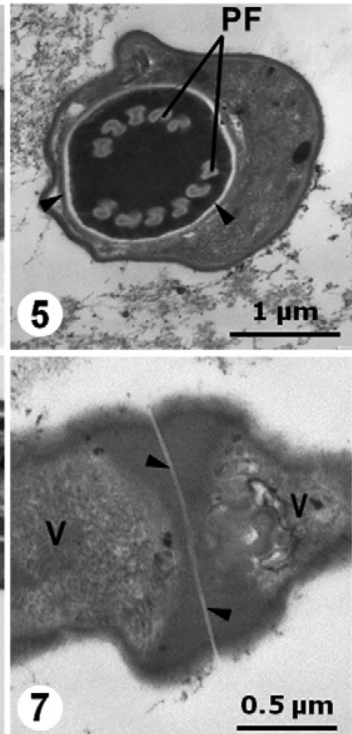

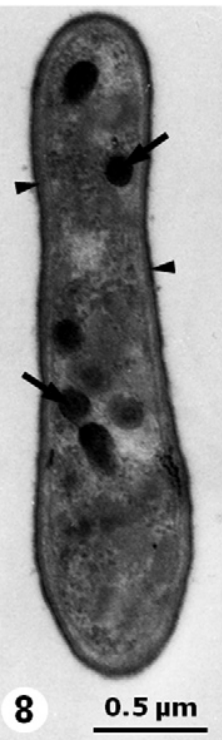

Figs 4-8: transmission electron micrographs of Ceratomyxa microlepis sp. nov. infecting the gall bladder of Hemiodus microlepis collected from the Amazon River. 4: ultrastructural detail of the two polar capsules in longitudinal section, displaying the organization of its polar filaments $(\mathrm{PF})$ and the extrusion pores (arrows) located at the spore anterior pole, near the sutural line (arrowheads). A nucleus (N) of the sporoplasm is observed close to these structures; 5: oblique section of a polar capsule (PC), allowing the recognition of its double-layer wall (arrowheads) and number of PF coils; 6: oblique section of the central region of a spore showing the PCs, one of the two Ns of the sporoplasm, some sporoplasmosomes (arrowheads) and a lipidic-like structure (arrow); 7: detailed aspect of the sutural line (arrowheads) uniting the two shell valves (V); 8: slightly oblique transverse section of a lateral projection containing numerous reserve bodies (arrows) and displaying the double-layer wall (arrowheads) organization of the spore shell Vs. 
gall bladder of Synodus foetans from the USA Atlantic Coast (Davis 1917), Ceratomyxa attenuata from the gall bladder of Scoliodon terranovae from the USA Atlantic Coast (Davis 1917) and Ceratomyxa koieae from the gall bladder of Sphyraena forsteri from Lizard Island in Australia (Gunter et al. 2010). On the other hand, comparative analysis of specific morphological characteristics of these species revealed some singular aspects that allow differentiation. C. aglomerata spores were less thick and the polar capsules slightly bigger, C. attenuata spores were of a similar shape, but much larger in length and thickness, as well as in the diameter of their polar capsules, and C. koieae spores displayed identical measurements, but had symmetrical shell valves (Davis 1917, Gunter et al. 2010). No specific similarity was observed to the spores of Ceratomyxa dissostichi, C. curvata and C. hippocampi, which were reported from the same geographical area, but from marine hosts (Cunha \& Fonseca 1918, Brickle et al. 2001).

Also taken into account were numerous molecular based studies that have revealed that the class Myxosporea is divided into two main clades: freshwater and marine species. C. shasta constitutes one of the few exceptions to this division, due to the anadromous nature of its host (Kent et al. 2001, Fiala \& Dyková 2004, Fiala 2006). Therefore, the parasite here described, which infects the gall bladder of a potamodromous fish, is more likely to be phylogenetically related to the other freshwater species within Ceratomyxa, rather than to the marine species with which it demonstrates an apparently higher level of morphological similarity.

The totality of comparative morphometric data analyzed, from both freshwater and marine species, combined with the specificity of the host geographical location, together suggest that this parasite is a new species, herein named C. microlepis sp. nov. Morphological comparisons were solely based on the mature spores' characteristics, since other developmental stages were not observed. The lack of vegetative and earlier sporogenic stages shows that during the hosts' collection period, the parasite had already incurred sporogenesis and full maturation. To conclude, the present paper constitutes the first description of a freshwater ceratomyxid from the South American region and the sixth report worldwide.

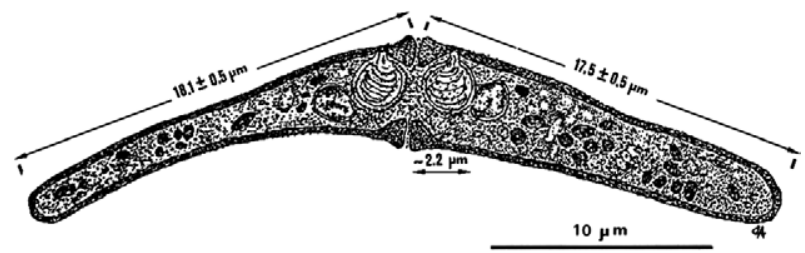

Fig. 9: schematic drawing of Ceratomyxa microlepis sp. nov. infecting the gall bladder of Hemiodus microlepis collected from the Amazon River, displaying the spore overall morphology, with special emphasis on the two opposite and asymmetric lateral projections of the shell valves.

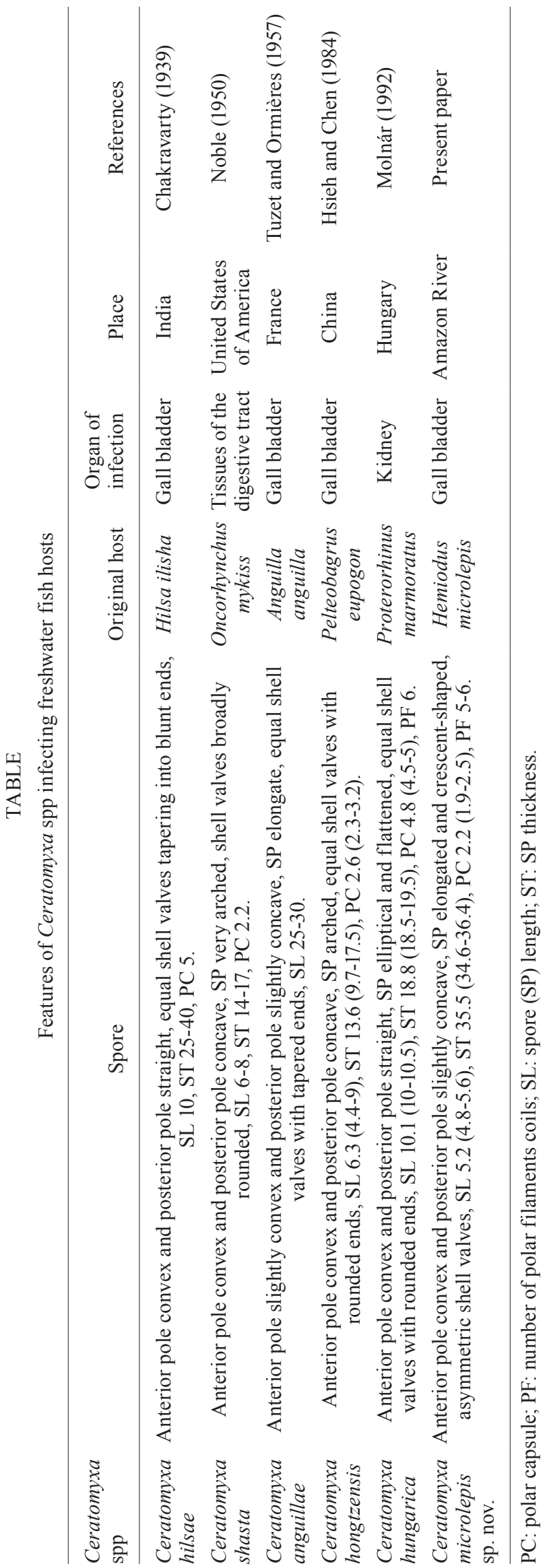




\section{ACKNOWLEDGEMENTS}

To Mr Karl Woodgett, for the English language proofreading of this paper.

\section{REFERENCES}

Abdel-Ghaffar F, Ali MA, Al Quraishy S, Al Rasheid K, Al Farraj S, Abdel-Baki AS, Bashtar AR 2008. Four new species of Ceratomyxa Thelohan 1892 (Myxozoa: Myxosporea: Ceratomyxidae) infecting the gallbladder of some Red Sea fishes. Parasitol Res 103: 559-565.

Ali M, Abdel-Baki AA, Sakran T 2006. Myxidium elmatboulii n. sp. and Ceratomyxa ghaffari n. sp. (Myxozoa: Myxosporea) parasitic in the gallbladder of the Red Sea houndfish Tylosurus choram (Rüppell, 1837) (Teleostei: Belonidae) from the Red Sea, Egypt. Acta Protozool 45: 97-103.

Brickle P, Kalavati C, MacKenzie K 2001. Two new species of myxozoan parasites (Myxosporea, Bivalvulida) from toothfish Dissostichus eleginoides Smitt, 1898 (Pisces, Nototheniidae). Acta Parasitol 46: 250-253.

Chakravarty M 1939. Studies on Myxosporidia from the fishes of Bengal, with a note on the myxosporidian infection in aquaria fishes. Arch Protistenkd 92: 169-178.

Cunha AM, Fonseca O 1918. Sobre os mixosporídios dos peixes do Brazil. Brasil-Médico 32: 691-694.

Davis HS 1917. The Myxosporidia of the Beaufort region, a systematic and biological study. Bull US Bur Fish 35: 199-252.

Eiras JC 2006. Synopsis of the species of the genus Ceratomyxa Thélohan, 1892 (Myxozoa: Myxosporea: Ceratomyxidae). Syst Parasitol 65: 49-71.

Fiala I 2006. The phylogeny of Myxosporea (Myxozoa) based on small subunit ribosomal RNA gene analysis. Int J Parasitol 36: $1521-1534$.

Fiala I, Dyková I 2004. The phylogeny of marine and freshwater species of the genus Chloromyxum Mingazzini, 1890 (Myxosporea:
Bivalvulida) based on small subunit ribosomal RNA gene sequences. Folia Parasitol 51: 211-214.

Gunter NL, Adlard RD 2008. Bivalvulidan (Myxozoa: Myxosporea) parasites of damselfishes with description of twelve novel species from Autralia's Great Barrier Reef. Parasitology 135: 1165-1178.

Gunter NL, Adlard RD 2009. Seven new species of Ceratomyxa Thélohan, 1892 (Myxozoa) from the gall-bladders of serranid fishes from the Great Barrier Reef, Australia. Syst Parasitol 73: 1-11.

Gunter NL, Burger MAA, Adlard RD 2010. Morphometric and molecular characterization of four new Ceratomyxa species (Myxosporea: Bivalvulida: Ceratomyxidae) from fishes off Lizard Island, Australia. Folia Parasitol 57: 1-10.

Hsieh XR, Chen QL 1984: A new species of myxosporidian parasite from freshwater fishes of China (Myxosporidia: Ceratomyxidae). Acta Zootaxon Sin 9: 337-339.

Kent ML, Andree KB, Bartholomew JL, El-Matbouli M, Desser SS, Devlin RH, Feist SW, Hedrick RP, Hoffmann RW, Khattra J, Hallett SL, Lester RJG, Longshaw M, Palenzeula O, Siddall ME, Xiao C 2001. Recent advances in our knowledge of the Myxozoa. J Eukaryot Microbiol 48: 395-413.

Lom J, Dyková I 1992. Myxosporidia (Phylum Myxozoa). Protozoan parasites of fishes. Developments in aquaculture and fisheries science, Vol. 26, Elsevier Science, Amsterdam, p. 159-235.

Lom J, Dyková I 2006. Myxozoan genera: definition and notes on taxonomy, life-cycle terminology and pathogenic species. Folia Parasitol 53: 1-36.

Molnár K 1992. Ceratomyxa hungarica $\mathrm{n}$. sp. and Chloromyxum proterorhini n. sp. (Myxozoa: Myxosporea) from the freshwater goby Proterorhinus marmoratus (Pallas). Syst Parasitol 22: 25-31.

Noble ER 1950. On a myxosporidian (protozoan) parasite of California trout. J Parasitol 36: 457-460.

Tuzet O, Ormières R 1957. Ceratomyxa anguillae nov. sp., myxosporidie parasite de la vesicule biliaire des anguilles de l'Étang de Thau. Ann Parasitol Hum Comp 32: 189-196. 